\title{
PATRONAT ŚWIĘTEGO OLAFA NAD KUPCAMI MORSKIMI I JEGO PRZEJAWY W TESTAMENTACH LUBECKICH BERGENFAHRER
}

\author{
Maciej Lubik (D) http://orcid.org/0000-0002-5893-4995 \\ Uniwersytet Zielonogórski
}

\author{
ABSTRACT \\ THE CULT OF ST. OLAF AMONG SEA MERCHANTS AND ITS \\ MANIFESTATION IN TESTAMENTS OF LÜBECK BERGENFAHRER
}

St. Olaf was one of the most vivid symbols of religious life in the northern part of medieval Europe. Many churches devoted to him were scattered across Scandinavian countries and his resting place in Nidaros (Trondheim) cathedral attracted numerous believers. As a patron saint of Norwegian kings and various organizations he seems to be a religious icon that permeated into some lay aspects of life, including the economic sphere. Although relatedness of his cult to sea is apparent in the oldest liturgical texts, Scandinavian sources pointed out in this article provide no certain evidence proving its relevancy to sea trade. However, in the Late Middle Ages St. Olaf's cult gained popularity among the Bergenfahrer - Lübeck sea merchants strongly involved in the commercial activity in Bergen. Testaments left by the Bergenfahrer constitute a set of evidence that illuminates the role that St. Olaf's cult played among this group of merchants. This role seems to be twofold: St. Olaf's cult was a symbol which shaped corporate identity of the Bergenfahrer, contributing to the organisational sphere of their activity, and provided spiritual support which shaped personal identity of individual merchants.

Keywords: St. Olaf, Lübeck, Bergen, Bergenfahrer, Hansa.

Słowa kluczowe: św. Olaf, Lubeka, Bergen, Bergenfahrer, Hanza.

Na początku XX wieku Friedrich Bruns opublikował krytyczne opracowanie źródeł do dziejów lubeczan zaangażowanych w handel z Bergen ${ }^{1}$, stanowiące nieoceniony zasób informacji na temat jednej z wyróżniających się grup kupców hanzeatyckich, tak zwanych Bergenfahrer. Zebrane przez badacza teksty pozwalają przyjrzeć

${ }^{1}$ F. Bruns, Die Lübecker Bergenfahrer und ihre Chronistik, Berlin 1900.

Adres do korespondencji: lubik.maciej@gmail.com 
się wielu wymiarom prowadzonej przez nich działalności. Jeden z nich stanowi kult św. Olafa, którego ślady są widoczne w spisanych przez kupców testamentach. Friedrich Bruns przytacza treść 231 tego typu dokumentów, które zostały spisane w latach 1307-1529. Bliższy wgląd w pozostawione zapiski wydaje się na tyle istotny, że pozwala silniej uchwycić kupiecki charakter kultu norweskiego świętego, który w źródłach skandynawskich trudno dostrzec. Choć lakoniczne, zapiski te pozwalają również odpowiedzieć na pytanie o rolę, jaką kult św. Olafa odgrywał pośród lubeckich Bergenfahrer - a wydaje się mieć ona dwojaki charakter.

Postać Olafa Haraldssona (ok. 995-1030) zalicza się do grona jednostek, które we własnej ojczyźnie odegrały ważną rolę zarówno w procesie państwotwórczym, jak i narodotwórczym. Zanim dostąpił tytułu świętego, wiódł morski żywot wikinga, który pozwolił mu zbudować na tyle silny autorytet, by następnie przejąć władzę w Norwegii. Ponad 10 lat jego rządów upłynęło pod znakiem chrystianizacji i centralizacji władzy, co przy ryzykownej polityce zagranicznej doprowadziło do wojny domowej i ostatecznie śmierci Olafa w bitwie pod Stiklestad. Mimo że nie brakowało przeciwników Olafa zarówno w samej Norwegii, jak i poza nią, kult tego pierwszego skandynawskiego świętego, a przy tym niebiańskiego opiekuna kolejnych norweskich władców, zaczął rozwijać się już niedługo po jego śmierci, by przez kolejne wieki kształtować tożsamość chrześcijańską nie tylko Norwegów, lecz także mieszkańców innych regionów północnej części Europy. Dedykowane mu kościoły powstawały w całej Skandynawii, jego grób w katedrze w Nidaros (dziś Trondheim) stał się jednym z najczęściej odwiedzanych centrów pątniczych chrześcijańskiego świata, a jego kult docierał niemal wszędzie tam, gdzie docierali Skandynawowie².

${ }^{2}$ Na temat działalności Olafa Haraldssona, a zwłaszcza jego kultu zob.: L. Daae, Norges Helgener, Christiania 1879, s. 13-133; O. Janse, Om Olofskult i Uppland [w:] Studier tillägnade Oscar Montelius, Stockholm 1903, s. 156-164; P. Nordmann, St. Olofs dyrkan i Finland, „Finsk tidskrift” 1912, s. 427-454; O. Kolsrud, Olavskyrkja i Trondheim, Oslo 1914; J. Schreiner, Tradisjon og saga om Olav den hellige, Oslo 1926; idem, Olav den hellige og nabolandene, „Historisk tidsskrift” 1927, 7/2, s. 22-76; A. Bugge, Hellig Olavs billede i middelalderens kunst, „Norsk teologisk tidsskrift” 1930, s. 81-92; Nidaros og Stiklestad. Olavs-jubileet 1930. Minneskrift, red. O. Kolsrud, Oslo 1930; M. Mackeprang, Hellig Olafs Dyrkelse i Danmark, „Det Kongelige Norske Videnskabs Selskab Forhandlinger” 1930, 3, s. 51-64; A. Schück, S:t Olofskulten i Sverige, „Nordisk tidskrift för vetenskap, konst och industri” 1930, s. 409-419; A. Seierstad, Den kyrkelege og den folkelege St. Olav, „Tidsskrift for Teologi og Kirke" 1930, s. 121-142; idem, Olavsdyrking i Nidaros og Nord-Europa, Nidaros 1930; B. Cnattingius, Sankt Olovsdyrkan i Linköpings stift, „Linköpings stifts julbok” 1931, s. 77-88; H. Fett, Hellig Olav. Norges evige Konge, Oslo 1938; O. Moberg, Olav Haraldsson, Knut den Store och Sverige. Studier i Olav den Heliges förhällande till de Nordiska grannländerna, Lund 1941; B. Dickins, The Cult of S. Olave in the British Isles, „Saga-Book of the Viking Society” 1945, 12, s. 53-80; C.A. Nordman, Olof den helige i Finlands medeltida konst, „Historiska och litteraturhistoriska studier" 1946, 21-22, s. 529-551; F.B. Wallem, B. Irgens Larsen, Iconographia Sancti Olavi, Trondheim 1947; O. Bø, Heilag-Olav i norsk folketradisjon, Oslo 1955; S:t Olof på Gotland 1029-1979, red. S.-E. Pernler, Skara 1979; Å. Ny man, Olofskult och Olofstraditioner i Jämtland, ,Jämten” 1980, 73, s. 25-42; Olav. Konge og helgen - myte og symbol, red. M. Blindheim, Oslo 1981; St. Olav. Seine Zeit und sein Kult, red. G. Svahnström, „Acta Visbyensia”, 6, Uddevalla 1981; V. Henriksen, Hellig Olav, Oslo 1986; L.R. Langslet, Olav den hellige, Oslo 1995; N.-A. Bringéus, Vallfärder till S:t Olof, Lund 1997; Helgonet i Nidaros. Olavskult och kristnande i Norden, red. L. Rumar, Stockholm 1997; A. Lidén, Olav den helige i medeltida bildkonst. Legendmotiv och attribut, Stockholm 1999; 
Niemałą przy tym rolę odegrały wodne szlaki handlowe - swoista płaszczyzna ekonomiczna rozwijająca morski/kupiecki charakter kultu św. Olafa, co stało się szczególnie wyraźne w świecie lubeckich handlarzy.

Łączenie postaci św. Olafa z morzem miało związek z jego życiem i legendą. Będąc wikingiem, pływał on po wodach okalających Północną i Zachodnią Europę, podobnie zresztą czynił po przejęciu rządów, odbywając władcze podróże wzdłuż wybrzeży Norwegii. Do motywu żeglarskiego odwołują się teksty liturgii na cześć św. Olafa (począwszy od połowy XI w.), a mający w niej swoje oparcie motyw św. Olafa jako cudownie przezwyciężającego wszelkie trudności żeglarza stanowi jeden z ważniejszych tematów średniowiecznej ikonografii skandynawskiej poświęconej jego postaci ${ }^{3}$. Olaf jako święty, przed którym wielka woda nie skrywa żadnych niebezpieczeństw, wyrósł przy tym na patrona kupców, dla których handel morski był głównym źródłem utrzymania. Zagadką jest, czy patronat nad kupcami morskimi stanowił cechę kultu norweskiego świętego, która z czasem wpisała się w specyfikę zawodową lubeckich handlarzy silnie zaangażowanych w kraju, któremu św. Olaf patronował, czy może cecha ta wykształciła się dopiero na niwie prowadzonej przez nich działalności.

Początki patronatu św. Olafa nad kupcami - w tym ich organizacjami - są dość niejasne, a doszukiwanie się ich w Skandynawii utrudnia znikomość i niejasność źródeł, które mamy do dyspozycji. Snorri Sturluson, autor spisanej w XIII wieku Heimskringli (sagi królewskiej), podaje, że w czasie rządów króla Olafa Pokojowego (1066-1093) przybierał w Norwegii na sile rozwój ośrodków miejskich, niektóre z nich były zakładane od podstaw, sam zaś król „założył kupieckie miasto w Bergen” (setti kaupstað in Bjorgyn). Sagamadra zaznacza również, że „Król Olaf [Pokojowy] założył Wielką Gildę w Nidaros i wiele innych w miastach kupieckich, gdzie wcześniej były towarzystwa biesiadne" (Óláfr konungr lét setja Miklagildi i Niðarósi ok

Olavslegenden og den latinske historieskrivning i 1100-tallets Norge, red. I. Ekrem, L.B. Mortensen, K. Skovgaard-Petersen, København 2000; T. Ljung, Sankt Olof $i$ Dalarna. Kult och vallfart, Falun 2001; H. Antonsson, The Cult of St. Ólafr in the Eleventh Century and Kievan Rus', „Middeladerforum" 2003, 1-2, s. 143-160; G. Røthe, Helt, konge og helgen. Den hagiografiske tradisjon om Olav den hellige i Den legendariske saga, Heimskringla og Flateyjarbók, Oslo 2004; S. Bagge, Warrior, King and Saint: The Medieval Histories about Óláfr Haraldsson, „Journal of English and Germanic Philology” 2010, 109/3, s. 281-321; J. Knuutila, Soturi, kuningas ja pyhimys. Pyhän Olavin kultti osana kristillistymistä Suomessa 1200-luvun alkupuolelta 1500-luvun puoliväliin, Helsinki 2010; J. Pysiak, Polityczne aspekty kultu świętego Olafa i relikwii Korony Cierniowej w norweskim konflikcie gregoriańskim (druga połowa XII-poczatek XIV wieku) [w:] Świat średniowiecza. Studia ofiarowane Profesorowi Henrykowi Samsonowiczowi, red. A. Bartoszewicz i in., Warszawa 2010, s. 525-551; M. Gąssowska, Der Heilige Olaf und Holmgård - Novgorod als Grenzraum zwischen Ost und West im 11.-12. Jahrhundert [w:] Rome, Constantinople and Newly-Converted Europe: Archaeological and Historical Evidence, red. M. Salamon i in., t. I, Kraków-Lepizig-Rzeszów-Warszawa 2012, s. 263-273; L. Jiroušková, Der heilige Wikingerkönig Olav Haraldsson und sein hagiographisches Dossier. Text und Kontext der Passio Olavi (mit kritischer Edition), t. I, Leiden-Boston 2014; S. Bagge, Olav den Hellige som norsk konge (1015-28), „Historisk tidsskrift” 2015, 94, s. 555-587; Helgenkongen St. Olav i kunsten, red. Ø. Ekroll, Trondheim 2016.

${ }^{3}$ A. Lidén, Sankt Olavs seglats i medeltida bild och legend: en bildpredikan i kyrkorummet [w:] Helgenkongen St. Olav i kunsten, s. 55-76. 
morg onnur i kaupstoðum, en aðr váru par hvirfingsdrykkjur $)^{4}$. W dwóch innych staronordyckich tekstach pojawiają się pewne sugestie wskazujące na związek kultu św. Olafa ze wspomnianą „Wielką Gildią” - Ágrip af Nóregskonungasogum (synoptyk, XII wiek) oraz Morkinskinna (saga królewska, XIII w.) krótko opisują uczestnictwo Olafa Pokojowego w spotkaniu Wielkiej Gildii, które, według przytaczanych słów króla, zorganizowano na cześć św. Olafa ${ }^{5}$. Przekazy te dały asumpt do tego, by sądzić, że wspomniana biesiada (samkunda) została zorganizowana z okazji dorocznego święta Wielkiej Gildii, przypadającego na dzień św. Olafa, a co za tym idzie norweski święty był tejże gildii patronem ${ }^{6}$. Wydaje się to jednak dość swobodną interpretacją. Nawet gdyby wspomniana biesiada została zorganizowana w obchodzone pod koniec lipca święto ku czci św. Olafa, nie stanowiłoby to większej podstawy do tego, by jednoznacznie zakładać, że Wielka Gildia funkcjonowała pod jego patronatem, jako że dzień św. Olafa, będąc jednym z ważniejszych świąt ówczesnej Norwegii, mógł być obchodzony powszechnie.

Warto przy tym zauważyć, że w świetle przekazu Snorriego Olaf Pokojowy był żywo zainteresowany nie tylko rozwojem handlu, lecz także umacnianiem kultu św. Olafa. Sagamadra podaje, że z jego polecenia wybudowano w Nidaros kamienną świątynię - nazwaną kościołem chrystusowym (Kristskirkja) - w miejscu pierwotnego pochówku św. Olafa. Ołtarz tejże świątyni ustawiono nad niegdysiejszym grobem świętego, nad ołtarzem zaś umieszczono relikwiarz z jego szczątkami ${ }^{7}$. Choć co do podawanych przez Snorriego szczegółów należy zachować dystans, to jednak bezsprzecznie kult św. Olafa, krewnego Olafa Pokojowego ${ }^{8}$, był istotny dla legitymizacji pozycji króla w ramach scentralizowanej struktury władzy, ciągle jeszcze w Norwegii krzepnącej. Ucztowanie na cześć świętego patronującego kolejnym spokrewnionym władcom Norwegii w towarzystwie zapewne wpływowych członków Wielkiej Gildii mogło być więc elementem prowadzonej przez króla polityki dynastycznej, niezależnie od tego, czy ową gildię oddano pod opiekę św. Olafa, czy też nie.

Jak zaznaczono wyżej, Snorri mówi również, że Olaf Pokojowy zakładał gildie w miastach kupieckich, gdzie wcześniej funkcjonowały zgromadzenia o charakterze

${ }^{4}$ Snorri Sturluson, Heimskringla (dalej: Heimskringla), red. Bjarni Aðalbjarnarson, wyd. 3, t. III, Reykjavík 2002, s. 204-205.

5 Ágrip af Nóregskonungasogum: A Twelfth-Century Synoptic History of the Kings of Norway (dalej: Ágrip), red. M.J. Driscoll, wyd. 2, London 2008, c. 44; Morkinskinna (dalej: Morkinskinna), red. Ármann Jakobs s on, Pórður Ingi Guðjóns son, t. I, Reykjavík 2011, s. 10.

${ }^{6}$ Por. K. Hege1, Städte und Gilden der germanischen Völker im Mittelalter, t. I, Leipzig 1891, s. 410-412; E. Hoffmann, König Olav Haraldsson als Heiliger des norwegischen Königshauses [w:] St. Olav. Seine Zeit..., s. 42.

${ }^{7}$ Heimskringla, s. 208; budowie kościoła chrystusowego prawdopodobnie towarzyszyła idea stworzenia mauzoleum władców Norwegii. Według tradycji ich szczątki oraz osób spokrewnionych zaczęto umieszczać w ścianach prezbiterium otaczających relikwiarz św. Olafa. Po utworzeniu arcybiskupstwa Nidaros (1152/1153) kościół ten był stopniowo przebudowywany na romańską katedrę, by później przekształcić się w budowlę gotycką (zob. Ø. Ekro1l, The Shrine of St Olav in Nidaros Cathedral [w:] The Medieval Cathedral of Trondheim: Architectural and Ritual Constructions in their European Context, red. M. Syrstad Andås i in., Turnhout 2007, s. 171, 173).

${ }^{8}$ Ojciec Olafa Pokojowego, Harald Hardrada, był przyrodnim bratem Olafa Haraldssona. 
towarzystw czy kół rozrywkowych/biesiadnych (hvirfingsdrykkjur). W zamyśle sagamadry więc gildie te mogły być usankcjonowanymi autorytetem króla kontynuatorami funkcjonujących od dawna stowarzyszeń. Tych natomiast nie da się powiązać z jakąkolwiek profesją na podstawie źródeł, którymi dysponujemy, o ile w ogóle grupowały one przedstawicieli określonych zawodów, co wydaje się wątpliwe. Kontynuatorką taką była najwyraźniej także Wielka Gildia9. W promowaniu kultu św. Olafa oraz powoływaniu do życia oficjalnych stowarzyszeń biesiadnych w miejsce wcześniej funkcjonujących można zatem dostrzegać działania Olafa Pokojowego mające na celu wzmocnienie własnej pozycji w państwie, a przy tym swojej kontroli nad rozwijającymi się ośrodkami miejskimi ${ }^{10}$.

Wątpliwą więc kwestią pozostaje nie tylko patronat św. Olafa nad Wielką Gildią, lecz także jej kupiecki charakter. Choć informację o utworzeniu Wielkiej Gildii w Nidaros oraz wielu innych gildii w miastach kupieckich Snorri umieszcza w kontekście przedsięwzięć Olafa Pokojowego zmierzających do rozwoju handlu w Norwegii oraz wynikających $\mathrm{z}$ tego zmian $^{11}$, to jednak kontekst ten nie daje mocnej podstawy do tego, by sądzić, iż gildie zakładane przez Olafa Pokojowego miały charakter stowarzyszeń kupieckich, tym bardziej że w XI wieku nie funkcjonowała w Norwegii osobna warstwa kupców. Do wykształcenia warstwy kupieckiej nie doszło w tym państwie w ciągu całego średniowiecza, toteż trudno również zakładać, że kupiecki charakter kontynuatora towarzystwa biesiadnego w Nidaros może być jedynie przeświadczeniem sagamadry, próbującego opisać minioną rzeczywistość odległą o około 130-170 lat z perspektywy własnych czasów, a przy tym na podstawie niełatwych dziś do zidentyfikowania źródeł ${ }^{12}$. Założenia tego nie wspierają inne zachowane świadectwa. Choć w czasach Snorriego mogła funkcjonować w Nidaros „gildia św. Olafa”, o której mówi dokument pochodzący z 1293 roku, to jednak i w tym wypadku charakter zawodowy stowarzyszenia pozostaje trudny do określenia. We wspomnianym dokumencie opat Arne z Holm oraz Eirik Thoressön z Lade poświadczają prawa kapituły katedralnej kościoła chrystusowego w Nidaros z czasów arcybiskupa Jona Raude (1268-1282) ${ }^{13}$. W świetle tekstu prawo do mianowania duchownych dla ,gildii św. Olafa oraz innych gildii”" (Olafs gilldi ok annur

${ }^{9}$ Co więcej, należy przy tym zwrócić uwagę, że użyte przez sagamadrę słowo gildi, zawarte w Miklagildi, może być intepretowane nie tylko jako gildia w rozumieniu stowarzyszenia/bractwa, lecz również jako uczta/biesiada. Biesiadne konotacje tego słowa umacniają założenie, że ustanawiane przez Olafa Pokojowego „gildie” były kontynuatorami wcześniejszych towarzystw rozrywkowych.

${ }_{10}$ Por. K. Hegel, op. cit., s. 408-412; E. Hoffmann, op. cit., s. 42-43.

${ }^{11}$ Sagamadra zaznacza, że niedługo po założeniu przez króla miasta kupieckiego w Bergen osiedliło się tam wielu bogatych ludzi oraz napłynęło zza morza wielu zagranicznych kupców.

${ }^{12}$ Zbliżone informacje odnośnie do rozwoju Bergen za panowania Olafa Pokojowego czy zaangażowania króla w umacnianiu kultu św. Olafa można znaleźć w innych intertekstualnie powiązanych z sobą sagach królewskich i synoptykach powstałych w drugiej połowie XII i pierwszej połowie XIII w. (zob. Ágrip, c. 44; Morkinskinna, s. 7, 10; Ágrip af Nóregskonungasogum. Fagrskinna-Nóregs konunga tal, red. Bjarni Einarsson, Reykjavík 1984, s. 299-300; Theodoricus, De antiquitate regum Norwagiensium. On the Old Norwegian Kings, red. E. Kraggerud, Oslo 2018, c. 29).

${ }_{13}$ Diplomatarium Norvegicum, t. III, Christiania 1853, nr 35, por. nr 34. 
gilldi) spoczywało w rękach tejże kapituły ${ }^{14}$. Brak przy tym dowodów na to, by gildia ta była kontynuatorką Miklagildi. Także w Túnsbergu działała gildia św. Olafa, na co wskazuje wprowadzone w 1276 roku prawo dla miast, według którego w siedzibie gildii św. Olafa w Túnsbergu miał gromadzić się tamtejszy logping. Nic jednak nie wiadomo na temat jej charakteru ${ }^{15}$. Gildia św. Olafa działała również w Onarheim (Sunnhordland - zachodnia Norwegia), w pierwszej połowie XIV wieku, na co wskazuje jej pieczęć złożona na jednym z dokumentów z 1344 roku ${ }^{16}$. Jak zauważył Max Pappenheim, zachował się również jej statut pochodzący z manuskryptu spisanego w 1394 roku $^{17}$. Jego treść nie wskazuje jednak na to, by była to gildia kupiecka. Karl Hegel zwraca również uwagę na zapiski poświadczające funkcjonowanie gildii św. Olafa w miastach szwedzkich - w Linköping, co potwierdzają dokumenty z 1301 i 1309 roku, oraz w Westerås, co potwierdza dokument z 1311 roku $^{18}$. Trudno powiedzieć, jaki był ich charakter, choć przypuszczać można, że kult św. Olafa był w czternastowiecznej Szwecji kojarzony z morzem, na co wskazuje pieczęć miejska z Torshälli z 1378/1379 roku, przedstawiająca św. Olafa zasiadającego w łodzi ${ }^{19}$. Co więcej, zachowała się także pieczęć gildii św. Olafa z tego miasta, datowana na 1275 rok $^{20}$. Gildia św. Olafa funkcjonowała również w Reykjahólar na Islandii. Poświadczone jest to dla 1119 roku w spisanej przed (być może kilka dekad wcześniej) 1250 rokiem Sadze o Porgilu i Hafliðim ${ }^{21}$. Z tekstu sagi można się dowiedzieć jedynie, że gildia zbierała się w dniu św. Olafa, gdy, jak zostało zaznaczone, można było handlować zbożem ${ }^{22}$. Prawdopodobnie więc zrzeszała ona gospodarzy i miała służyć jako podstawa organizacyjna do prowadzonych przez nich latem interesów. Być może podczas uczt wyprawianych 29 lipca przez jej członków wznoszono toast na cześć św. Olafa, którego formuła przetrwała w jednym z czternastowiecznych islandzkich manuskryptów ${ }^{23}$.

14 Zob. K. Hegel, op. cit., s. 411, 420.

15 Zob. Den nyere By-Lov eller Bjarkö-Ret [w:] Norges gamle love indtil 1387, red. R. Keyser, P.A. Munch, t. II, Christiania 1848, s. 187; K. Hegel, op. cit., s. 416.

${ }^{16} \mathrm{Na}$ pieczęci gildii, której patronatu treść dokumentu bezpośrednio nie określa, widnieje inskrypcja: „S: CONVIVARVM: BETI: OLAVI: DE: HONAREI” - „Pieczęć gildii św. Olafa z Onarheim” (Hyldingsbrev for Haakon Magnussön den yngre [w:] Norges gamle love indtil 1387, red. G. Storm, t. IV, Christiania 1885, s. 374).

17 M. Pappenheim, Ein altnorwegisches Schutzgildestatut, Breslau 1888, s. 3-4, 160-167; zob. V. Henriksen, op. cit., s. 240-241.

18 Badacz zaznacza, że gildie św. Olafa istniały również w Sztokholmie i Torshälli, jednakże nie podaje, skąd zaczerpnął informacje o nich (K. He gel, op. cit., s. 327-328).

19 A. Lidén, Olav, s. 94; eadem, Bilden av Sankt Olav [w:] Helgonet i Nidaros. Olavskult och kristnande $i$ Norden, red. L. Rumar, Stockholm 1997, s. 43.

20 Ibidem.

${ }^{21}$ M. Clunies Ross, The Cambridge Introduction to the Old Norse-Icelandic Saga, CambridgeNew York 2010, s. 18; Ólafur Ás geirs s on, Olav den helige på Island [w:] Helgonet i Nidaros. Olavskult och kristnande i Norden, red. L. Rumar, Stockholm 1997, s. 84-85.

${ }^{22}$ Thorgils saga ok Haflida [w:] Sturlunga Saga Including the Islendinga Saga of Lawman Sturla Thordsson and Other Works, red. Gudbrand Vigfus s on, t. I, Oxford 1878, s. 19.

${ }_{23}$ Diplomatarium Islandicum, t. II, Kaupmannahöfn 1893, s. 329; zob. V. Henriksen, op. cit., s. 253; Ólafur Ás geirsson, op. cit., s. 84-85. 
Przywołane źródła nie rozstrzygają o kupieckim charakterze kultu św. Olafa. Ze względu na siłę jego oddziaływania na Północy norweski święty mógł patronować wielu skandynawskim stowarzyszeniom, ale przynależność zawodowa członków tych, które wzmiankowane są w powyższych źródłach, pozostaje w dużej mierze niejasna. Z pewną ostrożnością można więc zakładać, że patronat św. Olafa nad kupcami nie został przejęty przez handlarzy lubeckich z tradycji skandynawskich, lecz to oni - ze względu na specyfikę swojej działalności i wiążące się z nią potrzeby - stali się niejako twórcami tego szczególnego wyróżnika późnośredniowiecznego kultu norweskiego świętego.

Rozwijane od XII wieku silne związki handlowe kupców niemieckich z kontynentalną Skandynawią, Gotlandią, a także Nowogrodem i Rewlem ${ }^{24}$ spowodowały, że kult św. Olafa zaczął docierać do miast północnych Niemiec. Szczególną rolę odgrywało w tych związkach Bergen, gdzie od początku XIII wieku zawijały statki lubeczan, którzy dobrze wpisywali się w potrzeby lokalnego rynku, przywożąc zboże sprowadzane ze wschodnich regionów Europy. W Bergen kupowali natomiast ryby, zwłaszcza suszonego dorsza, który dobrze sprzedawał się w miastach położonych w głębi Niemiec i dalej na obszarze Europy Środkowej. W mieście tym otrzymali oni prawo do założenia własnej dzielnicy handlowej - Deutsche Brücke ${ }^{25}$. Kupcy niemieccy związani z Bergen określani byli mianem Bergenfahrer, a duża ich część pochodziła z Lubeki i tworzyła własną gildię, która funkcjonowała już w 1380 roku.

Lubeccy Bergenfahrer dzielili się na dwie grupy: pierwszą, borger to Lubeck, stanowili bogatsi i starsi kupcy, stale przebywający w Lubece i zarządzający swoimi przedsiębiorstwami, w skład drugiej, copgeselle to Bergen, wchodzili z kolei ludzie młodzi, regularnie podróżujący do Bergen, spędzający sporo czasu w tamtejszym kantorze i tylko okazjonalnie zjawiający się w Lubece ${ }^{26}$. Związani z Bergen lubeczanie stali się głównym nośnikiem kultu św. Olafa pośród niemieckich kupców zaangażowanych w handel bałtycki. $\mathrm{W}$ ich macierzystym mieście powstawały charakterystyczne, dedykowane świętemu dzieła sztuki sakralnej (sprzedawane do

${ }^{24}$ P. Dollinger, Dzieje Hanzy (XII-XVII w.), thum. V. Soczewińska, Warszawa 1997, s. 22, 35, 37, 44-45, 216-221, 279-281; J. Schildhauer, Dzieje i kultura Hanzy, thum. B. Tarnas, Warszawa 1995, s. 21-26, 31-35; N. Blomkvist, The Discovery of the Baltic: The Reception of a Catholic World-System in the European North (AD 1075-1225), Leiden-Boston 2005, s. 378-379, 415, 420, 423. Zob. Norwegen und die Hanse. Wirtschaftliche und kulturelle Aspekte im europäischen Vergleich, red. V. Henn, A. Nedkvitne, Frankfurt am Main 1994. Na temat związków handlowych lubeczan i Gotlandczyków zob. K. Kumlien, Hansischer Handel und Hansekaufleute in Skandinavien. Einige Proble$m e$ [w:] Die Deutsche Hanse als Mittler zwischen Ost und West, red. A. von Brandt i in., Köln-Opladen 1963 , s. 83-87.

${ }^{25}$ J. Schildhauer, op. cit., s. 26; więcej na temat tej dzielnicy w: C. Schumann, Die deutsche Brücke in Bergen, „Hansische Geschichtsblätter”1889, 18, s. 55-125; na temat bergeńskiego kantoru hanzeatów zob.: Das Hansische Kontor zu Bergen und die Lübecker Bergenfahrer: International Workshop Lübeck 2003, red. A. Graßmann, Lübeck 2005; M. Burkhardt, Das Hansekontor in Bergen im Spätmittelalter - Organisation und Struktur, „Hansische Geschichtsblätter”2006, 124, s. 21-71; J. Wubs-Mrozewicz, Traders, Ties and Tensions: The Interaction of Lübeckers, Overijsslers and Hollanders in Late Medieval Bergen, Hilversum 2008.

${ }^{26}$ F. Bruns, op. cit., s. cxi-cxv; P. Dollinger, op. cit., s. 152. 
innych ośrodków $)^{27}$ oraz rozpowszechniła się legenda - niespotykana na obszarze Skandynawii - w której św. Olaf ponosi śmierć na wzór Jezusa. Zawarta jest ona w tak zwanym Pasjonale lubeckim, napisanym pod koniec XIV wieku i przetłumaczonym z łaciny na język dolnoniemiecki w $1505 \mathrm{roku}^{28}$, a wyrażona w niej modlitwa św. Olafa za nieprzyjaciół i w szczególności, jak zostało zaznaczone, „za kupców morskich, którzy wzywali go w swojej potrzebie" (vor de zevaren Kopmans, de ene in eren noden anropen), wskazuje na jej związek ze światem kupców hanzeatyckich.

Kult św. Olafa wiązał się również z innymi kupcami morskim (czy też szyprami) pochodzącymi z miejscowości zaangażowanych w handel na Bałtyku lub, w niektórych przypadkach, z działalnością kupiecką lubeczan na ich terenie - Stralsund, Wismar, Rostock, Brema, Gdańsk, Elbląg, Królewiec, Bardowick (nieopodal Lüneburga), Maastricht, Deventer, Amsterdam, Ryga ${ }^{29}$. Warto zaznaczyć, że - jak zauważa Lenka Jiroušková w swoim obszernym studium nad hagiografią św. Olafa - prawie wszystkie manuskrypty, które przetrwały do naszych czasów, zawierające dwie późnośredniowieczne wersje (z trzech, które w okresie całego średniowiecza się ukazały) najważniejszego tekstu hagiograficznego poświęconego św. Olafowi, Passio et Miracula Beati Olavi, są pochodzenia północnoniemieckiego, przy czym utrwaliły one legendę o tak zwanych cudownych regatach, w której św. Olaf, rywalizujący ze swoim przyrodnim bratem, przedstawiany jest jako niezłomny żeglarz, potrafiący w cudowny sposób pokonywać różne trudności pojawiające się na drodze swego statku $^{30}$. W przypadku wymienionych miejscowości recepcja kultu św. Olafa wydaje

${ }^{27}$ A. Lidén, Olav, s. 226-227, 229, 231, 259, 263-264, 320-321, 323-324, 362, 366-367.

${ }^{28}$ Passionel efte dat Leuent der Hyllighen, red. S. Arndes, Lübeck 1505 [w:] Scriptores Rerum Danicarum medii cevi, red. J. Langebek, t. II, Hafniæ 1773, s. 537-38; M. Blindheim, St. Olav ein skandinavischer Oberheiliger. Einige Beispiele der Literatur und der Bildkunst [w:] St. Olav. Seine Zeit..., s. 54-62. V. Henriksen wskazuje na jego inne wydania z lat 1492 i 1499. Zaznacza również, że legenda ta przetrwała także w wersji znanej ze Złotej Legendy, wydanej drukiem po łacinie w 1485 r. w Leuven (dzisiejsza Belgia). Najstarszy znany manuskrypt zawierający jej zbliżoną treść nie zachował się. Wiadomo jedynie, że przechowywany był w kościele Sint-Salvator w Utrechcie (dzisiejsza Holandia) i podejrzewa się, że został spisany w drugiej połowie XIV w. (eadem, op. cit., s. 301-304).

${ }_{29}$ Zob. M. Gąssowska, Kult świętych skandynawskich w krajach nadbaltyckich [w:] Podróżnicy, fundatorzy, święci, red. T. Ratajczak, Poznań 2008, s. 192-194; eadem, Święci królowie skandynawscy $w$ fundacjach ottarzowych w Gdańsku w XV wieku, „Studia Zamkowe” 2012, 4, s. 59-64; T. Mroczko, Kulte skandinavischer Heiligen in der mittelalterlichen Kunst Nordpolens [w:] St. Olav. Seine Zeit..., s. 217-234; M. Perlbach, St. Olavsgilden in Preussen, „Hansische Geschichtsblätter” 1901, 29, s. 170-176; W. Franz, Die geistlichen Brüderschaften Königsbergs im Mittelalter, „Prussia. Zeitschrift für Heimatkunde und Heimatschutz" 1940, 34, s. 155-210; A. Lidén, Sankt Olavsskåpet i Stralsund [w:] The Eighth International Saga Conference. Göteborg 11-17 August 1991. The Audience of the Sagas: Preprints, red. L. Lönnroth, t. I, Gothenburg 1991, s. 19-29; W. Stieda, Das Schonenfahrergelag in Rostock, „Hansische Geschichtsblätter” 1890/1891, 19, s. 115-150; J. Wubs-Mrozewicz, op. cit., s. 66, 95-96; K. Metting, Über die St. Olavgilde in Riga, „Sitzungsberichte der Gesellschaft für Geschichte und Altertumskunde der Ostseeprovinzen Russlands" 1904, s. 16-20; B.E. Bendixen, St. Olavs helgendyrkelse $i$ de tyske østersjøprovinser, „Bergens Historiske Forening" 1917, 23, s. 101-112; G. Baier, Zum Vorkommen von mittelalterlichen Darstellungen des Heiligen Olav im Norden der Deutschen Demokratische Republik [w:] St. Olav. Seine Zeit..., s. 189-198; A. Hofmeister, St. Olav in Rostock, „Hansische Geschichtsblätter” 1901, 29, s. 177-188.

${ }^{30}$ L. Jiroušková, op. cit., s. 571, 621-628; zob. A. Lidén, Sankt Olavs seglats, s. 69, 71. 
się mieć jednak charakter wtórny, polegający na przejęciu wzorców wypracowanych przez dominujących w handlu i kulturze hanzeatyckiej lubeczan.

Zanim w XV wieku w Lubece i innych miastach hanzeatyckich kult św. Olafa zyskał na popularności, nastąpił etap jego recepcji pośród niemieckich kupców przebywających, przynajmniej czasowo, w Bergen i na Gotlandii. W swoim testamencie z 1314 roku jeden z lubeckich handlarzy uczynił zapis na rzecz kościoła św. Olafa i św. Maryi w Visby, jednakże nie można stwierdzić z całą pewnością, że wynikało to $z$ jego oddania kultowi norweskiego świętego ${ }^{31}$. Wyraźniejszą informację na temat żywotności kultu św. Olafa pośród niemieckich kupców zawiera nieco wcześniejszy zapis testamentowy, z 1307 roku, w którym pewien lubecki Bergenfahrer, Thideman Wise, zobowiązał się na wypadek swojej śmierci i ku czci swojej duszy sfinansować dwie pielgrzymki - jedną do Nidaros, drugą zaś do Santiago de Compostela. Przeprowadzenie pierwszej powierzył swojemu bratu, który mieszkał w Bergen ${ }^{32}$.

Warto przy tym zauważyć, że liczba rozporząazeń testamentowych - w tym fundowanych w ten sposób pielgrzymek - zapisywanych ogółem przez lubeczan (niezależnie od profesji) wzrasta znacząco po wybuchu epidemii „czarnej śmierci” w Lubece około 1349/1350 roku ${ }^{33}$. Fakt, że spośród 231 zestawionych przez F. Brunsa testamentów Bergenfahrer aż 229 zostało sporządzonych po roku 1350 skłania do refleksji nad pytaniem, czy czynnikiem, który na trwałe zapoczątkował praktykę spisywania testamentów przez Bergenfahrer, była wspomniana zaraza, która w 1349 roku zaczęła szerzyć się również na terenach Skandynawii. Epidemia dżumy odpowiadała w Norwegii za śmierć co najmniej połowy populacji, przy czym dla roku 1349 zauważalny jest tam - choć należy mieć na uwadze niewielką ilość dostępnego materiału źródłowego - skokowy wzrost liczby zapisów testamentowych na rzecz Kościo$\mathrm{la}^{34}$. W przypadku testamentów Bergenfahrer zestawionych w pracy F. Brunsa trudno mówić o skokowym wzroście ich liczby dla okresu z okolic szczytu epidemii - tylko jeden dla roku $1351^{35}$ - jednak należy zauważyć, że podczas gdy F. Bruns wymienia jedynie dwa tego typu zapisy dla pierwszej połowy XIV wieku (lata 1307 i 1339) ${ }^{36}$, to już łącznie cztery dla lat 1351-135937. Mimo to wyraźny wzrost liczby testamentów sporządzanych przez Bergenfahrer widoczny jest dopiero od 1358 roku, a więc po upływie już dość sporego czasu od szczytu epidemii. W świetle analizowanych źródeł kwestię ewentualnego wpływu „czarnej śmierci” - czy jej pierwszej fali - na

${ }^{31}$ K. Friedland, Sankt Olav als Schutzpatron nordeuropäischer Kaufleute [w:] St. Olav. Seine Zeit..., s. 19; Regesten der Lübecker Bürgertestamente des Mittelalters (dalej: Regesten), red. A. von Brandt, t. I, Lübeck 1964, nr 46.

${ }^{32}$ K. Friedland, op. cit., s. 20; Regesten, t. I, nr 25, zob. t. II, nr 721; por. Die Testamente der Lübecker Bergenfahrer (dalej: Testamente), red. F. Bruns [w:] F. Bruns, op. cit., nr 1.

${ }_{33}$ A. von Brandt, Einleitung [w:] Regesten, s. 5-6; K. Friedland, op. cit., s. 20; por. H. Hölzel, „... pro salute anime mee ... ordino testamentum meum ... .". Studien zur Lübecker Kirchengeschichte im 14. Jahrhundert, „Zeitschrift des Vereins für Lübeckische Geschichte und Altertumskunde” 1990, 70, s. 46.

34 J. Małłek, Historia Norwegii (do roku 1814), Torun 2019, s. 211-219.

${ }_{35}$ Testamente, $\mathrm{nr} 3$.

36 Testamente, nr. 1-2.

${ }^{37}$ Testamente, nr. 3-6. 
zapoczątkowanie trwałej praktyki spisywania testamentów przez Bergenfahrer należy pozostawić jako nierozstrzygniętą. Warto jednak zwrócić uwagę na fakt, że wzrost liczby spisywanych przez Bergenfahrer testamentów zbiega się z kolejnymi zarazami, jakie dotknęły Lubekę w 1358 i 1367 roku - skutkiem tego jest znaczący wzrost liczby testamentów spisywanych ogółem przez lubeczan ${ }^{38}$ - po których nastąpiły epidemie w Norwegii w latach 1360 (choć ta ograniczona była do południowo-wschodniej części państwa) i 1370-1371 ${ }^{39}$. To plagi powtarzające się w ciągu 20 lat po wybuchu epidemii „czarnej śmierci” mogły uświadomić Bergenfahrer potrzebę uporządkowania swoich spraw majątkowych na wypadek śmierci, utrwalając pośród nich praktykę spisywania testamentów.

Kolejna prośba o pielgrzymkę do grobu św. Olafa w Nidaros została sporządzona w testamencie z roku 1358 roku przez lubeczanina Nicolausa von Hachede ${ }^{40}$, który najpewniej związany był z handlem w Norwegii. Liczba tego typu legatów zapisywanych przez Bergenfahrer zaczyna stopniowo wzrastać od roku 1380. Prócz wspomnianego Thidemana Wise pielgrzymów do grobu św. Olafa decydowali się wysłać: Nicolaus Sternenberch $(1380)^{41}$, Ludekinus Dinning (1381, ponownie w 1387$)^{42}$, Johan Witte $(1395)^{43}$, Johannes Grove $(1398)^{44}$, Johan Trage $(1419)^{45}$, Hermen Langhe $(1442)^{46}$, Hinrik Kemenade $(1451)^{47}$, Dyderik van dem Berghe $(1455)^{48}$ i Tydeke Grasshoff (1461, ponownie w 1468) ${ }^{49}$. Zdarzało się, że autor testamentu decydował się ufundować kilka tego rodzaju pielgrzymek, jak Johan Trage, który polecił wysłać po jednym pątniku do Nidaros, Jerozolimy, Rzymu, Akwizgranu oraz jednego do Thann i Einsiedeln. W 1434 roku co najmniej trzy pielgrzymki zdecydował się ufundować również Hinrik Tors - celem jednej z nich miał być kościół św. Olafa w Bergen (do którego miało udać się dwóch pątników), a pozostałych Jerozolima i Santiago de Compostela (po jednym pątniku) ${ }^{50}$.

Choć wzrost zainteresowania kultem św. Olafa pośród Bergenfahrer widać na przykładzie testamentów dopiero po 1380 roku, z pewnością zainteresowanie to zaczęło się wyraźniej przejawiać nieco wcześniej. Być może już w pierwszej połowie XIV wieku Bergenfahrer stali się łącznikami, dzięki którym kult norweskiego świętego znalazł swoje miejsce w Lubece, jako że najpóźniej w roku 1350 umieszczono w tamtejszym kościele mariackim wizerunek św. Olafa, przy którym, jak

38 A. von Brandt, op. cit., s. 6; por. H. Hölzel, op. cit., s. 46-47.

39 O.J. Benedictow, The Black Death and Later Plague Epidemics in the Scandinavian Countries: Perspectives and Controversies, Warsaw-Berlin 2016, s. 141, 175, 201-202, 204.

${ }^{40} \mathrm{H}$. Hölzel, op. cit., s. 40 (wraz z przypisem); zob. Regesten, t. II, nr 721.

41 Testamente, $\mathrm{nr} 35$.

42 Testamente, nr. 40, 45.

43 Testamente, nr 51.

44 Testamente, $\mathrm{nr} 55$.

45 Testamente, $\mathrm{nr} 76$.

46 Testamente, nr 115.

47 Testamente, nr 142.

48 Testamente, nr 149.

49 Testamente, nr 158.

50 Testamente, nr 99. 
dowiadujemy się ze spisanego w tymże roku testamentu Johanna Uphovela, odprawiane były msze ${ }^{51}$.

Niewątpliwie jednak kult norweskiego świętego zaczął na dobre rozwijać się w Lubece na przełomie XIV i XV wieku. W testamencie sporządzonym 1 kwietnia 1396 roku Bergenfahrer Ecbert Knokel zapisał legat na rzecz ołtarza św. Olafa, który miał zostać postawiony w kościele mariackim w Lubece ${ }^{52}$. Ponad cztery miesiące później kolejny Bergenfahrer, Albertus Grote, przeznaczył w swoim testamencie 30 marek lubeckich na prebendę związaną, jak można się domyślać, z planowaną przez Bergenfahrer kaplicą św. Olafa (ad vicariam, quam mercatores Bergenses sub turri ecclesie b. Marie in Lubeke fundare volunt $)^{53}$. Z kolei w przywołanym już testamencie z 1398 roku Johannes Grove zdecydował się ufundować stałą mszę, która miała być odprawiana przy ołtarzu Bergenfahrer dedykowanym św. Olafowi w kościele mariackim w Lubece, zapisując dodatkowo 10 marek lubeckich na tenże ołtarz ${ }^{54}$. Legaty te są dość wyraźnym przejawem religijnego organizowania się Bergenfahrer. Wspomniany ołtarz prawdopodobnie został postawiony przed końcem czerwca 1400 roku, a rok później ustanowiono prebendę powiązaną z powstałą w ten sposób kaplicą św. Olafa. Niekiedy przyjmuje się, że zgoda na budowę ołtarza mogła zostać wydana już w 1396 roku, kiedy to Ecbert Knokel i Albertus Grote spisali swoje testamenty, w zamian za udział gildii Bergenfahrer w sfinansowaniu budowy nowych organów w kościele mariackim - tak samo, jak było to w przypadku Schonenfahrer (kupców importujących śledzie ze Skanii) i postawionego przez nich ołtarza założenie to pozostaje jednak w sferze przypuszczeń ${ }^{55}$. W 1403 roku z kolei gildia Bergenfahrer zyskała prawo do zatrudniania księży ${ }^{56}$. Dedykowany świętemu ołtarz znajdował się nieopodal miejsca, w którym w roku 1350 umieszczony był jego wizerunek. Na początku XV wieku również w tym miejscu postawiono kamienną figurę rozmiarów człowieka, przedstawiającą siedzącego na tronie św. Olafa, trzymającego w prawej ręce berło, w lewej zaś jabłko, pod którego stopami (być może był to późniejszy dodatek) znajdował się smok ${ }^{57}$.

Św. Olaf był głównym, choć nie jedynym patronem ołtarza Bergenfahrer w kościele mariackim w Lubece. Dedykowany był on również Matce Bożej,

${ }^{51}$ Regesten, t. I, nr 305; F. Bruns, op. cit., s. cxxvi; K. Friedland, op. cit., s. 20.

52 Testamente, $\operatorname{nr} 52$.

53 Testamente, $\mathrm{nr} 53$.

${ }^{54}$ Testamente, nr 55.

${ }^{55}$ F. Bruns, op. cit., s. cxxvi-cxxvii.

${ }^{56}$ K. Friedland, op. cit., s. 21.

${ }_{57}$ M. Has se, Die Lübecker und ihre Heiligen und die Stellung des Heiligen Olav in dieser Schar. Die Heiligenverehrung in Lübeck während des Mittelalters [w:] St. Olav. Seine Zeit..., s. 182-183; niekiedy przyjmuje się, że figura ta mogła istnieć już w 1350 r., a na pewno nie powstała później niż w 1432 r. (Die Bau- und Kunstdenkmäler der Freien und Hansestadt Lübeck, red. F. Hirsch, G. Schumann, F. Bruns, t. II, Lübeck 1906, s. 304), jako że w tym czasie został spisany testament Hermena Paela, o którym dalej. Jeśli jednak przyjąć, że figura ta istniała już w 1350 r., należałoby ją utożsamiać z bliżej nieznanym wizerunkiem św. Olafa, znanym z testamentu Johanna Uphovela (F. Brun s, op. cit., s. cxxvi; zob. M. Gąssowska, Kult, s. 190). 
św. Sunnivie - patronce Bergen - i wszystkim świętym ${ }^{58}$. Powstanie kaplicy św. Olafa z pewnością nie było jednak konsekwencją śmierci Johannesa Grove, jako że w latach 1408-1416 pełnił on funkcję rajcy. Pozycję tę zawdzięczał przewrotowi, jaki dokonał się w Lubece w 1408 roku $^{59}$, kiedy to pospólstwo, od kilku dekad niezadowolone z władzy ekskluzywnego patrycjatu i konsekwencji złej sytuacji ekonomicznej miasta, obrało własną radę. Przez kolejnych osiem lat Lubeką targał konflikt między starą a nową radą, w trakcie którego każda starała się doprowadzić do uznania swojej legalności. Ostatecznie jednak zwyciężył patrycjat ${ }^{60}$. Według F. Brunsa Bergenfahrer należeli do mniej wpływowych kręgów społecznych - zwykle wywodzili się oni z niższych warstw, z miejscowości położonych w głębi lądu (zwłaszcza westfalskich), a wszystko, co zdołali w handlu zdobyć, zawdzięczali własnej pracy. Niekiedy, gdy udało im się już osiągnąć pewien stopień zamożności, ściągali do Lubeki swoich krewnych, angażując ich $\mathrm{w}$ handel z Norwegami ${ }^{61}$. To postrzeganie Bergenfahrer jako niezamożnej i niewiele znaczącej grupy społecznej jest obecnie, przynajmniej częściowo, kontestowane ${ }^{62}$ i choć nie należy zaliczać ich do pospólstwa, to jednak można zakładać, że szukali oni we wspomnianej rewolcie szans na poprawę, czy raczej wzmocnienie, swojej pozycji w Lubece w stosunku do najbardziej wpływowych grup. W ich wypadku więc recepcja kultu św. Olafa mogła wynikać z co najmniej dwóch względów pragmatycznych. Po pierwsze kult norweskiego świętego koncentrujący się w dedykowanej mu kaplicy w kościele mariackim mógł stanowić swego rodzaju ideologiczne i przede wszystkim organizacyjne podłoże w okresie konfliktu z patrycjatem. Należy przy tym zaznaczyć, że kaplica ta zapewne służyła głównie borger to Lubeck, którzy na stałe mieszkali w Lubece, dorobili się już pewnego majątku i mogli myśleć o walce o poprawę swojego statusu, zwłaszcza poprzez zyskanie wpływów we władzach miejskich. Po drugie zaś kult św. Olafa mógł być reprezentacyjnym wyznacznikiem tożsamości specyficznego środowiska, jakie stworzyli Bergenfahrer ${ }^{63}$, dzięki czemu mogli oni wyróżniać się pośród innych stowarzyszeń zawodowych (gildii/bractw czy cechów), które zwykle obierały sobie danego świętego na swojego patrona i oddawały mu cześć w wybranej świątyni ${ }^{64}$.

Jednakże kult św. Olafa nie miał dla Bergenfahrer jedynie instrumentalnego znaczenia. Wyrażane $\mathrm{w}$ testamentach prośby o zorganizowanie pielgrzymki do Nidaros za duszę zmarłego świadczą także o jego głębokim religijnym i osobistym charakterze. Obrazuje to zapis w testamencie Hermena Langhe, który w 1442 roku postanowił posłać do Nidaros pielgrzyma z zadaniem umieszczenia świecy (wykonanej z jednego lisfunta wosku) w kościele spoczynku św. Olafa, mającej palić

${ }^{58}$ F. Bruns, op. cit., s. cxxii.

${ }^{59}$ K. Friedland, op. cit., s. 21.

${ }^{60}$ P. Dollinger, op. cit., s. 257-260.

${ }^{61}$ F. Bruns, op. cit., s. cxxxix-cxlii.

${ }^{62}$ Zob. M. Burkhardt, The German Hanse and Bergen - New Perspectives on an Old Subject, „Scandinavian Economic History Review” 2010, 58/1, s. 60-79.

${ }_{63}$ Zob. K. Friedland, op. cit., s. 21-22.

${ }^{64}$ M. Has se, op. cit., s. 172-173; na temat bractw w Lubece w okresie średniowiecza zob. M. Zmy slony, Die Bruderschaften in Lübeck bis zur Reformation, Kiel 1977. 
się $\mathrm{w}$ intencji zbawienia duszy testatora ${ }^{65}$. Podobnie jak zapis testamentu sporządzonego w 1432 roku przez kupca Hermena Paela, w którym prosi, by po śmierci ciało jego zostało pochowane pod statuą św. Olafa, znajdującą się w obejściu (ummegange) kościoła mariackiego w Lubece ${ }^{66}$ (chodzi o wcześniej wspomnianą kamienną rzeźbę siedzącego św. Olafa), czy też zapis testamentu Tydekea Grashoffa z 1479 roku, w którym postanawia on wysłać do katedry w Nidaros obrazz wizerunkiem św. Olafa ${ }^{67}$. O wykraczaniu kultu św. Olafa poza emblematyczną sferę działalności kupieckiej na linii Lubeka-Bergen świadczą również inne donacje zapisane przez Bergenfahrer na rzecz katedry w Nidaros ${ }^{68}$ - gdzie znajdowały się najcenniejsze relikwie świętego - która zapewne kryje się pod stosowanym w niektórych testamentach określeniem „kościoła św. Olafa” w Nidaros ${ }^{69}$.

Do dwóch wspomnianych wyżej czynników pragmatycznych, które przyczyniły się do recepcji kultu św. Olafa pośród Bergenfahrer, należy więc również dodać czynnik wyłącznie religijny czy też psychologiczny. Zawód kupca pełen był niebezpieczeństw stanowiących zagrożenie dla zdrowia i życia, dlatego przed wyruszeniem w morze Bergenfahrer często spisywali testamenty, w których porządkowali swoje sprawy doczesne i duchowe, czyniąc odpowiednie zapisy na rzecz swoich bliskich, a także na cele religijne, by w razie zguby zapewnić zbawienie swojej duszy. Nie bez powodu $\mathrm{w}$ jednej z kaplic w lubeckim kościele mariackim umieszczono obraz przedstawiający katastrofę statku Bergenfahrera z napisem wzywającym do spowiedzi przed wyruszeniem w morze. Zwłaszcza w trakcie podróży, podczas długiej i monotonnej żeglugi, obsesja strachu przed sztormem czy napaścią piratów mogła dawać się we znaki ${ }^{70}$. Dlatego podejmując wyzwania rzucane przez wyprawy handlowe, kupcy ci, jak wszyscy inni (przede wszystkim udający się do ośrodków położonych $z$ dala od swoich rodzinnych stron), szukali duchowego wsparcia, a takie zapewniał im kult św. Olafa, który w XII wieku został określony „Wiecznym Królem Norwegii” (Rex Perpetuus Norwegie) ${ }^{71}$, tym samym będąc patronem kraju, dzięki któremu Bergenfahrer mogli zapewniać sobie utrzymanie i pomnażać swój majątek. Jednocześnie św. Olaf był kreowany w hagiografii i sztuce sakralnej na zwycięzcę wspomnianych „cudownych regat”, przed którego statkiem rozstępowały się góry i topił się ląd - zagrożenia, które czyhały na udających się do Bergen lubeckich kupców, podążających wzdłuż wybrzeży i przemierzających cieśniny. Choć kaplica św. Olafa w kościele mariackim służyła głównie borger to Lubeck, stale już mieszkającym w Lubece, ich dawne wyprawy handlowe do Bergen, podczas których ciężką i ryzykowną pracą powoli gromadzili swój majątek, sprawiły, że kult norweskiego świętego stał się na

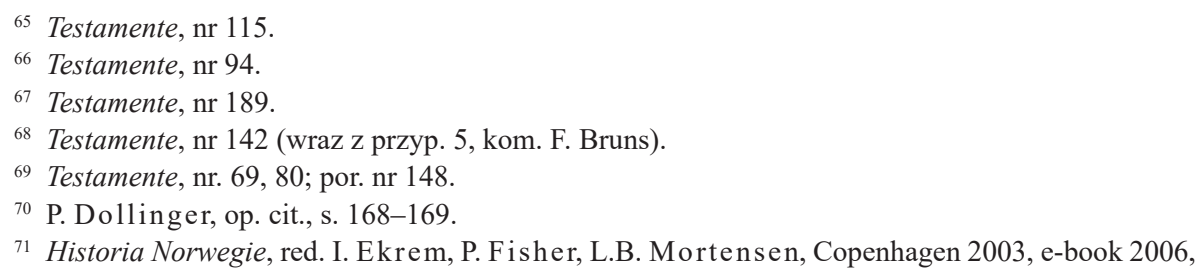


tyle trwałym elementem ich osobistej, a wyznacznikiem zbiorowej tożsamości, że nie zamierzali rozstawać się z nim w dalszej części swojego życia.

Zastanawiająca pozostaje kwestia lubeckich stowarzyszeń, którym patronował św. Olaf. Religijne organizowanie się gildii Bergenfahrer wokół kaplicy św. Olafa wskazuje, że funkcjonowała ona pod jego patronatem, jednakże żadne źródło nie informuje o tym wprost, choć wiadomo, że gildia pod takim wezwaniem istniała. Pierwsza o niej wzmianka pochodzi ze spisanego w 1400 roku testamentu jednego z Bergenfahrer, Hinrika Melebeke, w którym ten przekazał „gildii św. Olafa” (s. Olaves ghilde) trzy marki lubeckie na rzecz ołtarza św. Olafa ${ }^{72}$. Sugeruje to, że gildia Bergenfahrer, do której należała kaplica św. Olafa, mogła być znana również jako gildia św. Olafa. Następne zapiski testamentowe z XV wieku o gildii tej milczą, a kolejną wzmiankę można znaleźć w Kronice Chrystiana von Geren - wikarego, sekretarza-notariusza i kronikarza Bergenfahrer - obejmującej okres od roku 1350 do śmierci Chrystiana w roku $1486^{73}$. Z zapisów kroniki można się dowiedzieć, że latem 1480 roku „gildia św. Olafa była pijana” (war s. Olaves ghylde ghedrunken) - jej członkowie wyprawili ucztę, podczas której wybrali nowe władze gildii ${ }^{74}$. Również i ten zapis nie rozwiewa wątpliwości, czy pod nazwą „gildii św. Olafa” kryła się powstała w ostatnich dekadach XIV wieku gildia Bergenfahrer. Kolejne informacje o lubeckim stowarzyszeniu funkcjonującym pod patronatem św. Olafa pochodzą z szesnastowiecznych legatów Bergenfahrer. 9 stycznia 1515 roku Hans Rubenstrop zapisał na rzecz „bractwa św. Olafa” (broderscop s. Oleves) 20 guldenów reńskich $^{75}$, a 16 czerwca tego samego roku Brun Hoveman zapisał 10 marek lubeckich „bractwu św. Olafa” (broderschup s. Olavi), które, jak wynika ze słów kupca, miało się na nowo ukształtować w połączeniu z gildią Bergenfahrer (wenner de dorch de Bargerfarer angehaven wert by orem altar in Unser Leven Fruwen kerken under den tornen $)^{76}$. W roku następnym, 14 października, ten sam kupiec postanowił w kolejnym swoim testamencie dołożyć 200 marek lubeckich do najstarszej prebendy, dzięki której utrzymywany był ołtarz św. Olafa, oraz przeznaczyć 100 marek lubeckich „bractwu św. Olafa” (broderschup s. Olavi), gdyby było ono z prebendą tą związane $^{77}$. Wydaje się więc, że w okresie późnego średniowiecza w Lubece funkcjonowały dwa stowarzyszenia działające pod patronatem św. Olafa. Informacje o nich są dość skąpe i trudno powiedzieć, czy funkcjonowały one jednocześnie. „Gildia” św. Olafa działała już na początku XV wieku i z pewnością była aktywna w jego drugiej połowie. „Bractwo” św. Olafa powstało zaś w drugiej dekadzie XVI wieku. Być może było ono kontynuatorem ,gildii” św. Olafa (oba terminy, ,gildia” i „bractwo”, mogły być używane zamiennie), która z jakiegoś powodu zakończyła swoją działalność - zakładając, że gildia św. Olafa nie była stowarzyszeniem tożsamym z powstałą w ostatnich dekadach XIV wieku gildią Bergenfahrer, gdyż w przeciwnym razie

\footnotetext{
72 Testamente, $\mathrm{nr} 56$.

${ }^{73}$ F. Bruns, op. cit., s. 307-337.

${ }^{74}$ Die Chronik Christians von Geren, red. F. Bruns [w:] F. Bruns, op. cit., s. 374.

75 Testamente, $\mathrm{nr} 207$.

76 Testamente, $\mathrm{nr} 208$.

77 Testamente, $\mathrm{nr} 210$.
} 
nie miałyby sensu słowa o powstaniu owego bractwa w połączeniu z gildią Bergenfahrer. Gdyby jednak przyjąć, że gildia Bergenfahrer działała w Lubece jako gildia św. Olafa, to oznaczałoby, że od 1515 roku w mieście tym funkcjonowały połączone z sobą dwie organizacje, w których nazwach zaznaczony był patronat norweskiego świętego. Pewne jest jedynie to, że oba stowarzyszenia, „gildia” św. Olafa i „bractwo" św. Olafa, w jakimś stopniu funkcjonowały przy ołtarzu św. Olafa w kościele mariackim i zrzeszały w swoich szeregach Bergenfahrer.

Działający na miejscu w Bergen niemieccy kupcy, copgeselle to Bergen, również grupowali się w swoich stowarzyszeniach. Funkcjonowały one podług zasad, które obowiązywały członków kantoru bergeńskiego. Były to bractwa/gildie: św. św. Katarzyny i Doroty, Świętego Ciała, św. Barbary, Trójcy Świętej, św. Dunstana oraz św. Olafa ${ }^{78}$. Działająca w Bergen gildia św. Olafa wymieniana jest w testamentach z 1405 i 1438 roku i trudno przypuszczać, by była to ta sama gildia, która działała w Lubece do co najmniej 1480 roku. W testamencie z 1405 roku Johan Nyenborch zapisał trzy marki lubeckie na rzecz s. Oleves ghylde to Berghen ${ }^{79}$, z kolei w testamencie z 1438 roku Jorden Sasse zapisał pięć marek lubeckich to Berghen s. Olaves gylde, s. Katherinen gylde unde s. Dorotheen gylde ${ }^{80}$. W obu przypadkach zaznaczone jest, że chodzi o gildię św. Olafa, która działała w Bergen, nigdzie indziej. Warto dodać, że Johan Nyenborch zapisał również pięć marek lubeckich na ołtarz Bergenfahrer $\mathrm{w}$ kościele mariackim w Lubece.

Bractwo św. św. Katarzyny i Doroty prawdopodobnie było jednak głównym spośród stowarzyszeń kupców niemieckich w Bergen i również w jego przypadku kult św. Olafa odgrywał pewną rolę. Msze dla członków tego bractwa odprawiane były w dwóch kościołach św. Olafa w Bergen - jeden należał do tamtejszych dominikanów, drugi zaś do franciszkanów ${ }^{81}$ - a podczas uczt wyprawianych $\mathrm{w}$ dniu św. Katarzyny (25 listopada) oraz w dniu św. Doroty (6 lutego), po wzniesieniu toastów na cześć Trójcy Świętej, Świętego Ciała, św. św. Katarzyny i Doroty oraz św. Maryi Dziewicy, pito na cześć św. Olafa. Według sporządzonego w 1502 roku w księdze bractwa zapisku toast miał być wznoszony słowami: Sunte Olauus de grote König sinen beker, dat wy jn sineme lande also verkehren und kopschlagen, dat wy salich werden (,kielich za świętego Olafa, wielkiego króla, żebyśmy podróżowali i handlowali w jego kraju, żeby nie opuszczało nas szczęście"). Potem wznoszono toast za św. Jerzego, patrona rycerzy, by pomagał kupcom przezwyciężać trudności, oraz za panującego króla Norwegii, by rządził w miłosierdziu i pokoju, którymi

${ }^{78}$ J. Wubs-Mrozewicz, op. cit., s. 140-141, przyp. 87; F. Bruns, op. cit., s. 454-455; na temat gildii/bractw formujących się w Norwegii w okresie średniowiecza zob.: C. Anz, Gilden im mittelalterlichen Skandinavien, Göttingen 1998; G. Authén Blom, Ursprung der Gilden in Norwegen [w:] Gilde und Korporation in den nordeuropäischen Städten des späten Mittelalters, red. K. Friedland, Wien 1984, s. 5-28.

${ }^{79}$ Testamente, $\mathrm{nr} 59$.

${ }^{80}$ Testamente, $\mathrm{nr} 107$.

81 J. Wubs-Mrozewicz, op. cit., s. 140-141, przyp. 86. 
kupcy mogliby się cieszyć. Następnie członkowie bractwa wznosili toast za swoich przedstawicieli i współpracowników w Lubece ${ }^{82}$.

Niewątpliwie kult św. Olafa wpisał się na stałe w środowisko Bergenfahrer, a jego centrum w Lubece stanowiła dedykowana świętemu kaplica, którą zapewne również odwiedzali przybywający do miasta copgeselle to Bergen. Legaty na rzecz tejże kaplicy pojawiają się w testamentach Bergenfahrer zarówno przed utworzeniem - o czym wspomniano wyżej - oraz niedługo po jej utworzeniu, o czym mówią donacje na „ołtarz św. Olafa” czy „ołtarz Bergenfahrer”, które w swoich testamentach zapisali Hinrik Melebeke (1400) $)^{83}$, Jacob van Sehůsen $(1405)^{84}$, Johan Nyenborch $(1405)^{85}$, Kersten Nyestad (1406) ${ }^{86}$, Tydeman Voghel $(1406)^{87}$, Mathyas Bůrdeer $(1406)^{88}$. W nieco późniejszym okresie zapisy związane z funkcjonowaniem ołtarza/kaplicy św. Olafa w kościele mariackim w Lubece nie są już tak częste, przy czym do 1421 roku pojawiają się jeszcze w następujących po sobie kilkuletnich odstępach $(1410,1413,1416,1421)$. Dopiero druga połowa XV wieku ponownie przyniosła ich większą liczbę ${ }^{89}$. Co istotne, choć Bergenfahrer wielokrotnie zapisywali legaty na różne kościoły w Bergen (dość często jest to kilka tamtejszych świątyń wymienionych w jednym testamencie), to kaplica św. Olafa w kościele mariackim stanowi jedyny obiekt religijny w Lubece, $\mathrm{z}$ którego funkcjonowaniem wiąże się tak relatywnie duża liczba donacji zapisywanych przez owych kupców (jest ich jednak zdecydowanie mniej niż legatów na kościoły bergeńskie). Jednym z najważniejszych elementów kaplicy był relikwiarz św. Olafa, jaki znajdował się tam już w 1460 roku, o czym można dowiedzieć się z testamentu Hansa van Stendela, który ofiarował na niego markę srebra ${ }^{90}$. Jego wykonanie miało kosztować 24 marki lubeckie ${ }^{91}$. W roku 1476 z kolei ze spadku jednego z Bergenfahrer, Hinrika Mollera, ufundowana została (ku chwale Boga, Maryi Dziewicy, św. Olafa i wszystkich świętych) trzecia prebenda na rzecz duchownych zajmujących się ołtarzem św. Olafa ${ }^{92}$.

Duże znaczenie dla umocnienia kultu św. Olafa w Lubece miały testamenty Bruna Hovemana. W obu kupiec ten decydował się przeznaczyć odpowiednie kwoty na rzecz ołtarza św. Olafa. Ostateczną decyzję podjął jednak w swoim trzecim

82 Diplomatarium Norvegicum, t. XVI, Christiania 1901, nr 341; J. Wubs-Mrozewicz, op. cit., s. $142-143$.

${ }^{83}$ Testamente, $\mathrm{nr} 56$.

${ }^{84}$ Testamente, $\mathrm{nr} 58$.

${ }_{85}$ Testamente, $\mathrm{nr} 59$.

${ }^{86}$ Testamente, $\mathrm{nr} 60$.

87 Testamente, $\mathrm{nr} 61$.

${ }_{88}$ Testamente, $\mathrm{nr} 62$.

${ }^{89}$ Testamente, nr. 64, 68, 74, 80; por. nr. 101, 153, 155, 164, 173, 174, 178, 180 (zob. przyp. 4, kom. F. Bruns), 181, 185, 188, 190-192, 205-208, 210, 218, 220, 225, 228, 231.

${ }_{90}$ Testamente, nr 155 (przyp. 3, kom. F. Bruns).

${ }_{91}$ Das Schüttingsrechnungsbuch. 1469-1530, red. F. Bruns [w:] F. Bruns, op. cit., s. 244.

92 Testamente, nr 180 (zob. przyp. 4, kom. F. Bruns); Nachrichten zur Geschichte der kirchlichen Stiftungen der Bergenfahrer (dalej: Stiftungen), red. F. Bruns [w:] F. Bruns, op. cit., nr. 3, 8; druga została ufundowana w 1411 r. przez Johanna Holste ku czci Maryi Dziewicy, św. Barbary i św. Gertrudy (Stiftungen, nr 2; F. Bruns, op. cit., s. cxxix). 
testamencie, spisanym 20 marca 1521 roku, w którym zdecydował się przeznaczyć aż 1000 marek lubeckich na budowę drugiego ołtarza w kaplicy św. Olafa oraz związaną z nim prebendę ${ }^{93}$. Należy przy tym zwrócić uwagę na decyzję wykonawców testamentu Titekea Rolevesa ${ }^{94}$, którzy w 1522 roku samodzielnie postanowili przeznaczyć część pozostawionego w spadku majątku na wykonanie relikwiarza dla nowego ołtarza ${ }^{95}$.

Warto również wspomnieć, że w omawianym okresie miejscem spotkań członków ekskluzywnego bractwa Cyrkla, zrzeszającego najbardziej wpływowych ludzi w Lubece, był tzw. Olausburg. Spotkania te służyły zarówno celom towarzyskim, jak i dobijaniu różnorakich interesów. Olausburg nie stanowił jednak własności bractwa, lecz należał do rady miejskiej ${ }^{96}$. Nazwa budynku nadana na cześć św. Olafa sugeruje, że jego postać zyskała w Lubece popularność także poza kręgami Bergenfahrer. Podczas rozruchów wywołanych przez reformację Olausburg został spustoszony ${ }^{97}$. To właśnie ruch reformacyjny, a także upadek znaczenia Hanzy w dobie nowych stosunków ekonomicznych opartych na handlu oceanicznym zadecydowały o zaniku kultu św. Olafa pośród kupców niemieckich.

$\mathrm{Na}$ podstawie przytoczonych źródeł nie możemy jednoznacznie ustalić, czy kult św. Olafa wiązany był przez rodzimych mieszkańców Skandynawii z handlem morskim. Jednak dzięki jego niezwykle silnej pozycji w chrześcijaństwie Północy, a także dzięki jego żeglarskim konotacjom oraz patronatowi roztaczanemu przez świętego nad państwem norweskim, rozwijające się związki handlowe kupców niemieckich ze Skandynawią stały się nową płaszczyzną, na której kult ten zyskał kolejną możliwość rozwoju, wywierając przy tym znaczący wpływ na kształtowanie się tożsamości Bergenfahrer. Pośród lubeckich kupców kult św. Olafa odgrywał dwojaką rolę. $Z$ jednej strony był symbolem zwornikiem, zarówno kształtującym ich tożsamość grupową, jak i ułatwiającym organizację, czemu służyła dedykowana św. Olafowi kaplica w kościele mariackim w Lubece oraz funkcjonujące pod jego patronatem stowarzyszenia kupieckie. $Z$ drugiej zaś strony kult św. Olafa zapewniał kupcom duchowe wsparcie, wychodząc naprzeciw naturalnym potrzebom wynikającym z wykonywania niebezpiecznego zawodu, a jednocześnie oddziałując na tożsamość indywidualną poszczególnych Bergenfahrer na tyle wyraźnie, że poprzez wyrażaną w swoich testamentach wolę wiązali oni z kultem św. Olafa swoje pośmiertne losy. Oba te czynniki stanowiły o sile kultu św. Olafa pośród dominujących w handlu północnoeuropejskim lubeczan, dzięki czemu zaczął on zyskiwać popularność także wśród innych hanzeatów.

${ }^{93}$ Stiftungen, nr. 5, 8 .

94 Testamente, nr 218 (zob. przyp. 3, kom. F. Bruns).

${ }_{95}$ Stiftungen, nr 7; F. Bruns, op. cit., s. cxxxi.

${ }_{96}$ C.F. Wehrmann, Das Lübeckische Patriziat, „Zeitschrift des Vereins für Lübeckische Geschichte und Altertumskunde" 1888, 5, s. 307-309.

97 Ibidem, s. 330. 


\section{BIBLIOGRAFIA}

\section{Źródła}

Agrip: Ágrip af Nóregskonungasogum: A Twelfth-Century Synoptic History of the Kings of Norway, red. M.J. Driscoll, wyd. 2, London 2008.

Ágrip af Nóregskonungasogum. Fagrskinna - Nóregs konunga tal, red. Bjarni Einarsson, Reykjavík 1984.

Den nyere By-Lov eller Bjarkö-Ret [w:] Norges gamle love indtil 1387, red. R. Keyser, P.A. Munch, t. II, Christiania 1848, s. 179-290.

Die Chronik Christians von Geren, red. F. Bruns [w:] F. Bruns, Die Lübecker Bergenfahrer und ihre Chronistik, Berlin 1900, s. 348-381.

Das Schüttingsrechnungsbuch. 1469-1530, red. F. Bruns [w:] F. Bruns, Die Lübecker Bergenfahrer und ihre Chronistik, Berlin 1900, s. 237-284.

Diplomatarium Islandicum, t. II, Kaupmannahöfn 1893.

Diplomatarium Norvegicum, t. III, Christiania 1853.

Diplomatarium Norvegicum, t. XVI, Christiania 1901.

Heimskringla: Snorri Sturluson, Heimskringla, red. Bjarni Aðalbjarnarson, t. III, Reykjavík 2002.

Historia Norwegie, red. I. Ekrem, P. Fisher, L.B. Mortensen, Copenhagen 2003, e-book 2006.

Hyldingsbrev for Haakon Magnussön den yngre [w:] Norges gamle love indtil 1387, red. G. Storm, t. IV, Christiania 1885, s. 373-374.

Morkinskinna: Morkinskinna, red. Ármann Jakobsson, Pórður Ingi Guðjónsson, t. II, Reykjavík 2011.

Passionel efte dat Leuent der Hyllighen, red. S. Arndes, Lübeck 1505 [w:] Scriptores Rerum Danicarum medii cevi, red. J. Langebek, t. II, Hafniæ 1773, s. 535-539.

Regesten: Regesten der Lübecker Bürgertestamente des Mittelalters, red. A. von Brandt, t. I-II, Lübeck 1964-1973.

Stiftungen: Nachrichten zur Geschichte der kirchlichen Stiftungen der Bergenfahrer, red. F. Bruns [w:] F. Bruns, Die Lübecker Bergenfahrer und ihre Chronistik, Berlin 1900, s. 291-304.

Testamente: Die Testamente der Lübecker Bergenfahrer, red. F. Bruns [w:] F. Bruns, Die Lübecker Bergenfahrer und ihre Chronistik, Berlin 1900, s. 5-151.

Theodoricus, De antiquitate regum Norwagiensium. On the Old Norwegian Kings, red. E. Kraggerud, Oslo 2018.

Thorgils saga ok Haflida [w:] Sturlunga Saga Including the Islendinga Saga of Lawman Sturla Thordsson and Other Works, red. Gudbrand Vigfus s on, t. I, Oxford 1878, s. 7-39.

\section{Opracowania}

Antonsson H., The Cult of St. Olafr in the Eleventh Century and Kievan Rus', ,Middeladerforum" 2003, 1-2, s. 143-160.

Anz C., Gilden im mittelalterlichen Skandinavien, Göttingen 1998.

Ás geirs s on Ólafur, Olav den helige på Island [w:] Helgonet i Nidaros. Olavskult och kristnande i Norden, red. L. Rumar, Stockholm 1997, s. 83-90. 
Bagge S., Olav den Hellige som norsk konge (1015-28), „Historisk tidsskrift” 2015, 94, s. 555-587.

Bagge S., Warrior, King and Saint: The Medieval Histories about Óláfr Haraldsson, „Journal of English and Germanic Philology" 2010, 109/3, s. 281-321.

Baier G., Zum Vorkommen von mittelalterlichen Darstellungen des Heiligen Olav im Norden der Deutschen Demokratische Republik [w:] St. Olav. Seine Zeit und sein Kult, red. G. Svahnström, „Acta Visbyensia”, 6, Uddevalla 1981, s. 189-198.

Bendixen B.E., St. Olavs helgendyrkelse i de tyske østersjøprovinser, „Bergens Historiske Forening" 1917, 23, s. 101-112.

Benedictow O.J., The Black Death and Later Plague Epidemics in the Scandinavian Countries: Perspectives and Controversies, Warsaw-Berlin 2016.

Blindheim M., St. Olav - ein skandinavischer Oberheiliger. Einige Beispiele der Literatur und der Bildkunst [w:] St. Olav. Seine Zeit und sein Kult, red. G. Svahnström, „Acta Visbyensia", 6, Uddevalla 1981, s. 53-68.

Blom Authén G., Ursprung der Gilden in Norwegen [w:] Gilde und Korporation in den nordeuropäischen Städten des späten Mittelalters, red. K. Friedland, Wien 1984, s. 5-28.

Blomkvist N., The Discovery of the Baltic: The Reception of a Catholic World-System in the European North (AD 1075-1225), Leiden-Boston 2005.

Brandt von A., Einleitung [w:] Regesten der Lübecker Bürgertestamente des Mittelalters, red. A. von Brandt, t. I, Lübeck 1964, s. 5-12.

Bringéus N.-A., Vallfärder till S:t Olof, Lund 1997.

Bruns F., Die Lübecker Bergenfahrer und ihre Chronistik, Berlin 1900.

Bugge A., Hellig Olavs billede i middelalderens kunst, „Norsk teologisk tidsskrift” 1930, s. 81-92.

Burkhardt M., Das Hansekontor in Bergen im Spätmittelalter - Organisation und Struktur, „Hansische Geschichtsblätter” 2006, 124, s. 21-71.

Burkhardt M., The German Hanse and Bergen - New Perspectives on an Old Subject, „Scandinavian Economic History Review” 2010, 58/1, s. 60-79.

Bø O., Heilag-Olav i norsk folketradisjon, Oslo 1955.

Cnattingius B., Sankt Olovsdyrkan i Linköpings stift, „Linköpings stifts julbok” 1931, s. $77-88$.

Clunies Ross M., The Cambridge Introduction to the Old Norse-Icelandic Saga, Cambridge-New York 2010.

Daae L., Norges Helgener, Christiania 1879.

Das Hansische Kontor zu Bergen und die Lübecker Bergenfahrer: International Workshop Lübeck 2003, red. A. Graßmann, Lübeck 2005.

Dickins B., The Cult of S. Olave in the British Isles, „Saga-Book of the Viking Society” 1945, 12, s. 53-80.

Die Bau- und Kunstdenkmäler der Freien und Hansestadt Lübeck, red. F. Hirs ch, G. Schumann, F. Bruns, t. II, Lübeck 1906.

Dollinger P., Dzieje Hanzy (XII-XVII w.), thum. V. Soczewińska, Warszawa 1997.

Ekroll Ø., The Shrine of St Olav in Nidaros Cathedral [w:] The Medieval Cathedral of Trondheim: Architectural and Ritual Constructions in their European Context, red. M. Syrstad Andås i in., Turnhout 2007, s. 147-207.

Fett H., Hellig Olav. Norges evige Konge, Oslo 1938.

Franz W., Die geistlichen Brüderschaften Königsbergs im Mittelalter, „Prussia. Zeitschrift für Heimatkunde und Heimatschutz" 1940, 34, s. 155-210. 
Friedland K., Sankt Olav als Schutzpatron nordeuropäischer Kaufleute [w:] St. Olav. Seine Zeit und sein Kult, red. G. Svahnström, „Acta Visbyensia”, 6, Uddevalla 1981, s. $17-25$.

Gąs sowska M., Der Heilige Olaf und Holmgård - Novgorod als Grenzraum zwischen Ost und West im 11.-12. Jahrhundert [w:] Rome, Constantinople and Newly-Converted Europe: Archaeological and Historical Evidence, red. M. Salamon i in., t. I, KrakówLepizig-Rzeszów-Warszawa 2012, s. 263-273.

Gąs sowska M., Kult świętych skandynawskich w krajach nadbattyckich [w:] Podróżnicy, fundatorzy, święci, red. T. Ratajczak, Poznań 2008, s. 184-196.

Gąssowska M., Święci królowie skandynawscy $w$ fundacjach ołtarzowych $w$ Gdańsku w XV wieku, „Studia Zamkowe” 2012, 4, s. 59-64.

Hasse M, Die Lübecker und ihre Heiligen und die Stellung des Heiligen Olav in dieser Schar. Die Heiligenverehrung in Lübeck während des Mittelalters [w:] St. Olav. Seine Zeit und sein Kult, red. G. Svahnström, „Acta Visbyensia”, 6, Uddevalla 1981, s. 171-188. Hegel K., Städte und Gilden der germanischen Völker im Mittelalter, t. I, Leipzig 1891.

Helgenkongen St. Olav i kunsten, red. Ø. Ekro11, Trondheim 2016.

Helgonet i Nidaros. Olavskult och kristnande i Norden, red. L. Rumar, Stockholm 1997.

Henriksen V., Hellig Olav, Oslo 1986.

Hoffmann E., König Olav Haraldsson als Heiliger des norwegischen Königshauses [w:] St. Olav. Seine Zeit und sein Kult, red. G. Svahnström, „Acta Visbyensia”, 6, Uddevalla 1981, s. 35-44.

Hofmeister A., St. Olav in Rostock, „Hansische Geschichtsblätter” 1901, 29, s. 177-188.

Hölzel H., ,,... pro salute anime mee ... ordino testamentum meum ...”. Studien zur Lübecker Kirchengeschichte im 14. Jahrhundert, ,Zeitschrift des Vereins für Lübeckische Geschichte und Altertumskunde" 1990, 70, s. 27-69.

Janse O., Om Olofskult i Uppland [w:] Studier tillägnade Oscar Montelius, Stockholm 1903, s. 156-164.

Jiroušk ková L., Der heilige Wikingerkönig Olav Haraldsson und sein hagiographisches Dossier. Text und Kontext der Passio Olavi (mit kritischer Edition), t. I, Leiden-Boston 2014.

Knuutila J., Soturi, kuningas ja pyhimys. Pyhän Olavin kultti osana kristillistymistä Suomessa 1200-luvun alkupuolelta 1500-luvun puoliväliin, Helsinki 2010.

Kolsrud O., Olavskyrkja i Trondheim, Oslo 1914.

Kumlien K., Hansischer Handel und Hansekaufleute in Skandinavien. Einige Probleme [w:] Die Deutsche Hanse als Mittler zwischen Ost und West, red. A. von Brandt i in., Köln-Opladen 1963, s. 79-102.

Langs let L.R., Olav den hellige, Oslo 1995.

Lidén A., Bilden av Sankt Olav [w:] Helgonet i Nidaros. Olavskult och kristnande i Norden, red. L. Rumar, Stockholm 1997, s. 26-49.

Lidén A., Olav den helige i medeltida bildkonst. Legendmotiv och attribut, Stockholm 1999.

Lidén A., Sankt Olavs seglats i medeltida bild och legend: en bildpredikan i kyrkorummet [w:] Helgenkongen St. Olav i kunsten, red. Ø. Ekroll, Trondheim 2016, s. 55-76.

Lidén A., Sankt Olavsskåpet i Stralsund [w:] The Eighth International Saga Conference. Göteborg 11-17 August 1991. The Audience of the Sagas: Preprints, red. L. Lönnroth, t. I, Gothenburg 1991, s. 19-29.

Ljung T., Sankt Olof i Dalarna. Kult och vallfart, Falun 2001.

Małłek J., Historia Norwegii (do roku 1814), Toruń 2019.

Moberg O., Olav Haraldsson, Knut den Store och Sverige. Studier i Olav den Heliges förhällande till de Nordiska grannländerna, Lund 1941.

Mroczko T., Kulte skandinavischer Heiligen in der mittelalterlichen Kunst Nordpolens [w:] St. Olav. Seine Zeit und sein Kult, red. G. Svahnström, „Acta Visbyensia”, 6, Uddevalla 1981, s. 217-234. 
Nidaros og Stiklestad. Olavs-jubileet 1930. Minneskrift, red. O. Kolsrud, Oslo 1930.

Nordman C.A., Olof den helige i Finlands medeltida konst, „Historiska och litteraturhistoriska studier" 1946, 21-22, s. 529-551.

Nordmann P., St. Olofs dyrkan i Finland, „Finsk tidskrift” 1912, s. 427-454.

Norwegen und die Hanse. Wirtschaftliche und kulturelle Aspekte im europäischen Vergleich, red. V. Henn, A. Nedkvitne, Frankfurt am Main 1994, s. 9-18.

Nyman Å., Olofskult och Olofstraditioner i Jämtland, „Jämten” 1980, 73, s. 25-42.

Mackeprang M., Hellig Olafs Dyrkelse i Danmark, „Det Kongelige Norske Videnskabs Selskab Forhandlinger" 1930, 3, s. 51-64.

Olav. Konge og helgen - myte og symbol, red. M. Blindheim, Oslo 1981.

Olavslegenden og den latinske historieskrivning i 1100-tallets Norge, red. I. Ekrem, L.B. Mortensen, K. Skovgaard-Petersen, København 2000.

Pappenheim M., Ein altnorwegisches Schutzgildestatut, Breslau 1888.

Perlbach M., St. Olavsgilden in Preussen, „Hansische Geschichtsblätter” 1901, 29, s. $170-176$.

Pysiak J., Polityczne aspekty kultu świętego Olafa i relikwii Korony Cierniowej w norweskim konflikcie gregoriańskim (druga połowa XII-początek XIV wieku) [w:] Świat średniowiecza. Studia ofiarowane Profesorowi Henrykowi Samsonowiczowi, red. A. Bartoszewicz i in., Warszawa 2010, s. 525-551.

Røthe G., Helt, konge og helgen. Den hagiografiske tradisjon om Olav den hellige i Den legendariske saga, Heimskringla og Flateyjarbók, Oslo 2004.

Schildhauer J., Dzieje i kultura Hanzy, thum. B. Tarnas, Warszawa 1995.

Schumann C., Die deutsche Brücke in Bergen, „Hansische Geschichtsblätter” 1889, 18, s. $55-125$.

Schreiner J., Olav den hellige og nabolandene, „Historisk tidsskrift” 1927, 7/2, s. 22-76.

Schreiner J., Tradisjon og saga om Olav den hellige, Oslo 1926.

Schück A., S:t Olofskulten i Sverige, „Nordisk tidskrift för vetenskap, konst och industri” 1930, s. 409-419.

Seierstad A., Den kyrkelege og den folkelege St. Olav, „Tidsskrift for Teologi og Kirke” 1930, s. 121-142.

Seierstad A., Olavsdyrking i Nidaros og Nord-Europa, Nidaros 1930.

St. Olav. Seine Zeit und sein Kult, red. G. Svahnström, „Acta Visbyensia”, 6, Uddevalla 1981.

S:t Olof på Gotland 1029-1979, red. S.-E. Pernler, Skara 1979.

Stieda W., Das Schonenfahrergelag in Rostock, „Hansische Geschichtsblätter” 1890/1891, 19 , s. $115-150$.

Wallem F.B., Irgens Larsen B., Iconographia Sancti Olavi, Trondheim 1947.

Wehrmann C.F., Das Lübeckische Patriziat, „Zeitschrift des Vereins für Lübeckische Geschichte und Altertumskunde" 1888, 5, s. 293-392.

Wubs-Mrozewicz J., Traders, Ties and Tensions: The Interaction of Lübeckers, Overijsslers and Hollanders in Late Medieval Bergen, Hilversum 2008.

Zmyslony M., Die Bruderschaften in Lübeck bis zur Reformation, Kiel 1977. 